\title{
ASSESSING THE SUITABILITY OF GROUNDWATER FOR DRINKING AND AGRICULTURAL USES IN THE ZACHARO BASIN, SW PELOPONNESUS
}

\author{
Panagopoulos G. ${ }^{1}$, Lambrakis N. ${ }^{2}$, Chalvantzis C. ${ }^{1}$, Bekiari V. ${ }^{3}$ and \\ Avramidis P. ${ }^{2}$ \\ ${ }^{1}$ Technological Educational Institute of Western Greece, Department of Mechanical Engineering \\ T.E., 26334,Patras, Greece, gpanagopoulos@teimes.gr,chrchalv@teimes.gr \\ ${ }^{2}$ University of Patras, Department of Geology, 26500,Rio, Greece,nlambrakis@upatras.gr, \\ p.avramidis@upatras.gr \\ ${ }^{3}$ Technological Educational Institute of Western Greece, Department of Fisheries - Aquaculture \\ Technology, 30200, Messolonghi, Greece, mpekiari@teimes.gr
}

\begin{abstract}
The hydrochemical character of the Zacharo basin groundwaters and their suitability for drinking and irrigation purposes are evaluated in this paper. The Pindos karst aquifer, the Neogene and the alluvial aquifer are the three most important aquifers of the study area. 46 water samples were taken from wells, boreholes and spring and they analyzed for the physicochemical parameters ( $\mathrm{pH}, \mathrm{EC}$ and TOC), major ions $\left(\mathrm{Ca}^{2+}, \mathrm{Mg}^{2+}, \mathrm{Na}^{+}, \mathrm{K}^{+}, \mathrm{NH}_{4}^{+}, \mathrm{HCO}_{3}{ }^{-}, \mathrm{Cl}^{-}, \mathrm{F}^{-}, \mathrm{SO}_{4}{ }^{2-}\right.$ and $\left.\mathrm{NO}_{3}{ }^{-}\right)$and trace metals $(\mathrm{B}, \mathrm{Fe}$, $\mathrm{Mn}, \mathrm{Cr}, \mathrm{Pb}, \mathrm{Se}, \mathrm{Ni}$ ). The suitability of groundwaters for drinking and irrigation is evaluated by the calculation of Water Quality Index and the indices SAR, \%Na, RSC and KR. The water of the karstic and alluvial aquifer is of "excellent" quality for both uses. On the other hand, the Neogene aquifer shows serious problems in respect with the degradation of water quality, since 20\% of the samples are of "poor" and "extremely poor" quality for drinking purposes and 33\% are "unsuitable" for irrigation. The degradation of water quality is attributed to natural processes of enhanced ion-exchange, since the cation exchange capacity of the aquifer materials is increased due to the presence of clay minerals and organic matter.
\end{abstract}

Keywords: aquifer, hydrochemistry, water quality index, ion-exchange.

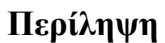

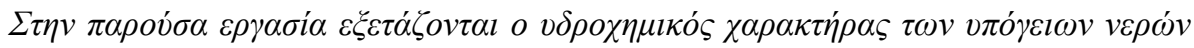

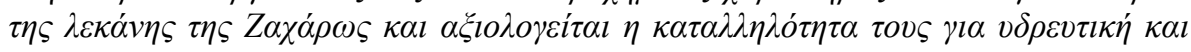

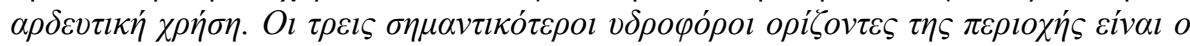

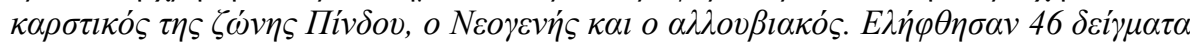

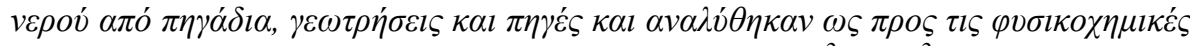

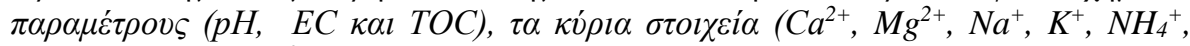

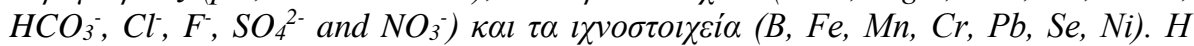

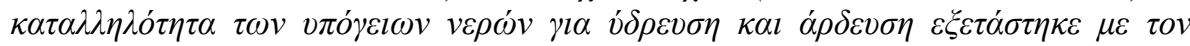

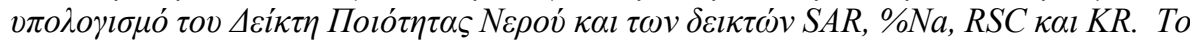

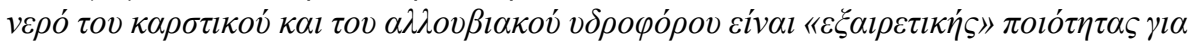

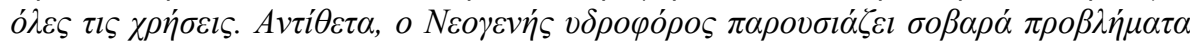




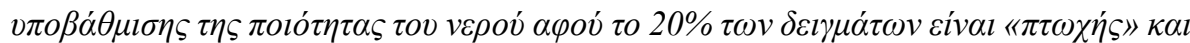

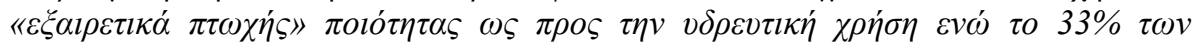

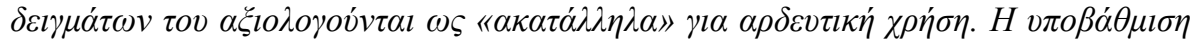

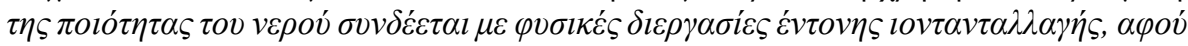

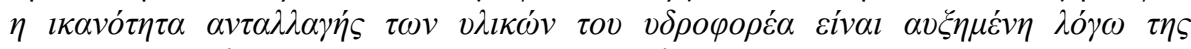

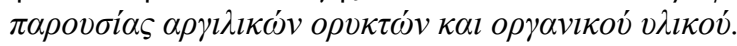

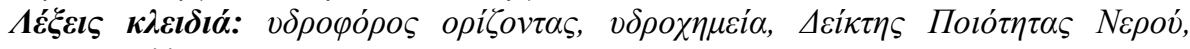

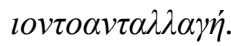

\section{Introduction}

The study area occupies part of the Neogene basin of Zacharo, SW Peloponnesus, covering 98.5 $\mathrm{km} 2$ area with a population of 9,000 inhabitants. According to the data of the local meteorological station, the mean annual rainfall height and temperature is $813 \mathrm{~mm}$ and $17.9^{\circ} \mathrm{C}$, respectively (hydrological period 2007 - 2015). The rainiest period is between December and January, whereas the period of lowest precipitation is between July and August. Zacharo is an agricultural area with olive trees and vineyards while tourism plays important role for the local economy during the summer period. As a result, water resources are progressively stressed during last decades due to the increased water demands for drinking and irrigation purposes, especially in the dry summer season.

The groundwater quality of the study area is influenced by both human activities and natural processes of geological origin. The combination of several water quality indexes has been proved as an effective tool for planners and decision makers in selecting appropriate groundwater management practices (Vasanthavigar et al., 2010; Ravikumar et al., 2013; Amiri et al., 2015). The aim of this paper is the evaluation of the suitability of groundwater for drinking and irrigations as well as to find out the possible sources of contamination that may affect the water quality in Zacharo basin.

\section{Geology and Hydrogeology}

The geological and hydrogeological regime of the study area was assessed from the Geological map of I.G.M.E. and in situ observations (Fig. 1). The geological bedrock of Zacharo basin consists of limestones and radiolarites of Pindos zone. The carbonate sediments comprise a very productive karst aquifer, which is used for covering the drinking demands of Zacharo municipality. Large springs are formed in the contact of limestones with the impermeable radiolarites. In the northern part of Kaiafas area, the carbonate bedrock of Tripolis zone has been emerged and constitutes a very important aquifer but its use is limited to therapeutic thermal baths due to its high temperature and salinity (Kallergis and Lambrakis, 1992).

The Pliocene sediments overlies the carbonate bedrock and consist of compact conglomerates which alternate with fine-grained and coarse-grained sandstones and grey-yellow marls. The sequence includes locally thin coal seams, usually $3-5 \mathrm{~cm}$ thick. The Neogene sediments form confined aquifers due to the presence of impermeable marly beds. This aquifer is used mainly for irrigation because of the degraded water quality.

Finally, the alluvial deposits occupy the coastal area and consist of sand, pebbles, fluvial deposits and terraces, cobbles and loams. This formation is more finely grained in the wider Kaiafas lake area showing a lacustrine origin. On the other hand, the formation is more coarsely grained and has a thickness of $40 \mathrm{~m}$ (Panagopoulos and Lambrakis, 1999) in the Neda river basin near Giannitsochori village (Fig. 1). These sediments host an extensive unconfined aquifer which is used for covering both drinking and irrigation demands. 


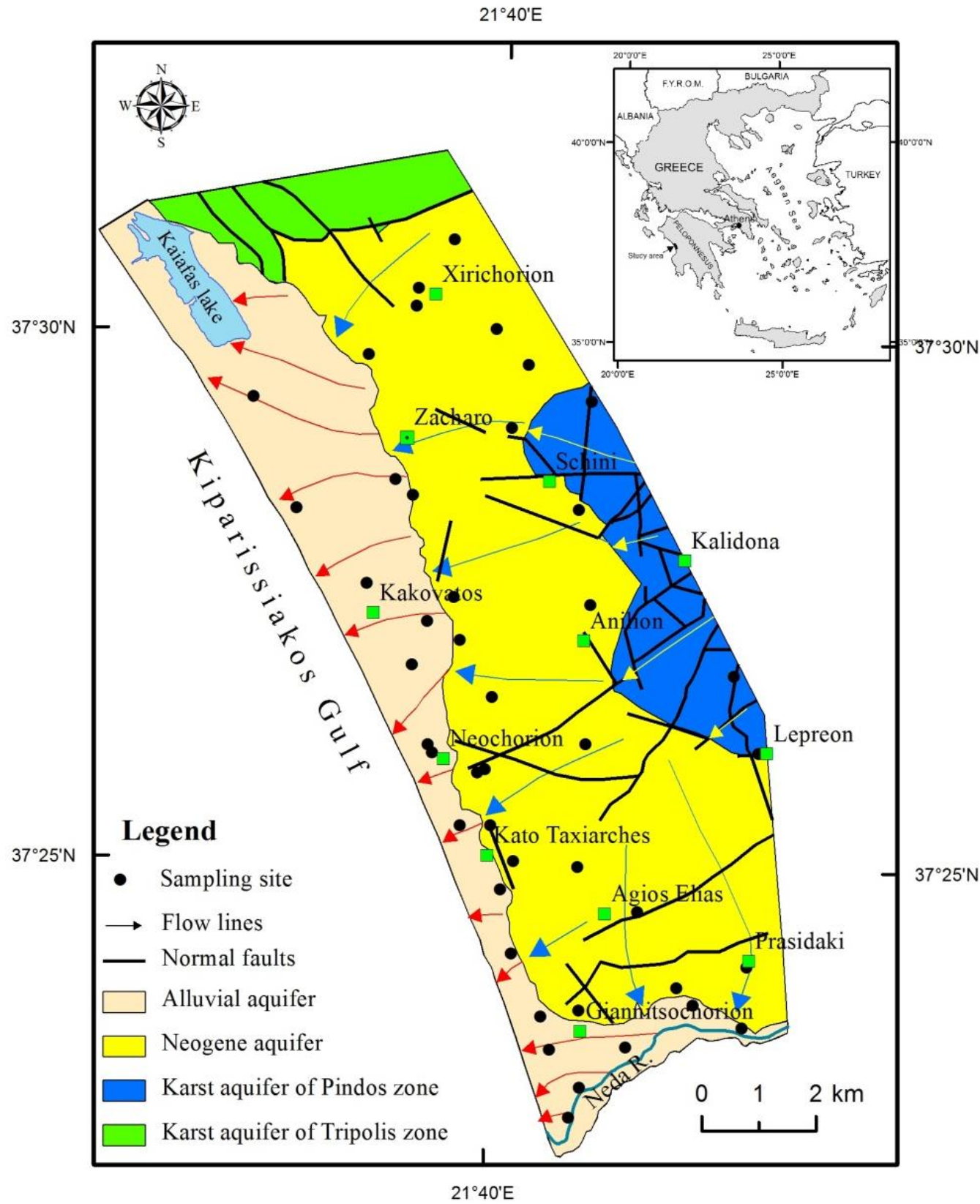

Figure 1 - Simplified hydrogeological map of the Zacharo basin.

The piezometry of all aquifers was studied by water table measurements carried out in a network of 60 boreholes and wells. A general NE-SW groundwater flow direction was figured out for all aquifer systems (Fig. 1) which coincides with the major normal fault trend of the study area. 


\section{Materials and Methods}

\subsection{Sampling and Analytical Techniques}

Groundwater from the three aquifers (alluvial, Neogene and karstic) from 46 public and private wells, boreholes and springs was sampled and analyzed seasonally during April 2013 and October 2013 (wet and dry season respectively). The samples were analyzed for major ions $\left(\mathrm{Ca}^{2+}, \mathrm{Mg}^{2+}, \mathrm{Na}^{+}\right.$, $\mathrm{K}^{+}, \mathrm{NH}_{4}{ }^{+}, \mathrm{HCO}_{3}{ }^{-}, \mathrm{Cl}^{-}, \mathrm{F}^{-}, \mathrm{SO}_{4}{ }^{2-}$ and $\mathrm{NO}_{3}{ }^{-}$) and Total Organic Carbon (TOC) in the laboratory of Geology for Aquatic Systems, T.E.I. of Western Greece. Trace and heavy metals (B, Fe, Mn, Cr, $\mathrm{Pb}, \mathrm{Se}, \mathrm{Ni}$ ) were determined in the laboratory of Hydrogeology, University of Patras. The unstable parameters of water like temperature, electric conductivity (EC) and $\mathrm{pH}$ were measured in situ. The standard analytical procedures as recommended by APHA (2005) were employed. Based on the results of chemical analyses, irrigation quality parameters like SAR, \% Na, RSC, KR, PI, were also calculated. The results are presented in Table 1.

\subsection{Water Quality Index}

Water Quality Index (WQI) is defined a rating method that provides the composite influence of individual water quality parameters on the overall quality of water for human consumption (Poonam et al., 2013). The computation of WQI includes three steps. In the first step, each of the 20 parameters ( $\mathrm{pH}, \mathrm{EC}, \mathrm{TOC}, \mathrm{Ca}^{2+}, \mathrm{Mg}^{2+}, \mathrm{Na}^{+}, \mathrm{K}^{+}, \mathrm{NH}_{4}^{+}, \mathrm{HCO}_{3}^{-}, \mathrm{Cl}^{-}, \mathrm{F}^{-}, \mathrm{SO}_{4}{ }^{2-}$ and $\mathrm{NO}_{3}{ }^{-}, \mathrm{B}, \mathrm{Fe}, \mathrm{Mn}$, $\mathrm{Cr}, \mathrm{Pb}, \mathrm{Se}, \mathrm{Ni}$ ) has been assigned a weight (wi) according to their perceived effects on human health and their relative importance in the overall quality of water for drinking purposes (Table 2). The highest weight of 5 was assigned to parameters that have a major effect on water quality $\left(\mathrm{NH}_{4}{ }^{+}, \mathrm{F}^{-}\right.$, $\mathrm{NO}_{3}{ }^{-}$and the heavy metals $\mathrm{Mn}, \mathrm{Cr}, \mathrm{Pb}, \mathrm{Se}$ and $\mathrm{Ni}$ ). A weight of 3 was assigned to parameters with a moderate effect on human health ( $\mathrm{pH}, \mathrm{EC}, \mathrm{TOC}, \mathrm{Na}^{+}, \mathrm{Cl}^{-}$and $\mathrm{SO}_{4}{ }^{2-}$ ) while a weight of 2 was assigned to parameters with the lowest effect respectively $\left(\mathrm{Ca}^{2+}, \mathrm{Mg}^{2+}, \mathrm{K}^{+}, \mathrm{HCO}_{3}{ }^{-}, \mathrm{B}\right.$ and $\left.\mathrm{Fe}\right)$. In the second step, the relative weight is computed from the following equation:

$W_{i}=w_{i} \sum_{i=1}^{n} w_{i}$

where $\mathrm{Wi}$ is the relative weight, wi is the weight of each parameters and $\mathrm{n}$ is the number of parameters.

In the third step, a quality rating scale (qi) for each parameter is assigned by dividing its concentration in each water sample by its respective standard value (DWS) according to the guidelines of European Union (Table 1) and then, the result is multiplied by 100:

$q_{i}=\left(\frac{C_{i}}{S_{i}}\right) x 100$

where qi is the quality rating, $\mathrm{Ci}$ is the concentration of each chemical parameter in each water sample in milligrams per liter and $\mathrm{Si}$ is the European drinking water standard for each chemical parameter.

Finally, for computing the WQI, the water quality sub-index (SIi) has to be calculated according to the equation $\mathrm{SIi}=\mathrm{Wi} \cdot \mathrm{qi}$, which is then used to determine the WQI as per the following equation:

$\mathrm{WQI}=\sum_{i=1}^{n} S I_{i}$ 
Table 1 - Hydrochemical data of Zacharo basin aquifers (April 2013).

\begin{tabular}{|c|c|c|c|c|c|c|c|c|}
\hline \multirow[b]{2}{*}{ Parameter } & \multirow[b]{2}{*}{ Unit } & \multirow[b]{2}{*}{ DWS } & \multicolumn{2}{|c|}{ Karstic } & \multicolumn{2}{|c|}{ Alluvial } & \multicolumn{2}{|c|}{ Neogene } \\
\hline & & & Mean & $\begin{array}{c}\% \\
\text { exceed }\end{array}$ & Mean & $\begin{array}{c}\% \\
\text { exceed }\end{array}$ & Mean & $\begin{array}{c}\% \\
\text { exceed }\end{array}$ \\
\hline pH & & 8.5 & 7.31 & 0 & 7.27 & 0 & 7.55 & 10 \\
\hline EC & $\mu \mathrm{S} / \mathrm{cm}$ & 2500 & 583 & 0 & 843 & 0 & 1260 & 5 \\
\hline TOC & $\mathrm{mg} / \mathrm{L}$ & 2 & 0 & 0 & 0.45 & 10 & 5.76 & 62 \\
\hline $\mathrm{Ca}$ & $\mathrm{mg} / \mathrm{L}$ & 75 & 95.4 & 80 & 101.9 & 65 & 96.5 & 67 \\
\hline Mg & $\mathrm{mg} / \mathrm{L}$ & 50 & 6.2 & 0 & 24.0 & 5 & 25.8 & 24 \\
\hline $\mathrm{Na}$ & $\mathrm{mg} / \mathrm{L}$ & 200 & 14.1 & 0 & 30.2 & 0 & 129.8 & 10 \\
\hline K & $\mathrm{mg} / \mathrm{L}$ & 12 & 1.1 & 0 & 2.8 & 0 & 3.2 & 0 \\
\hline $\mathrm{NH}_{4}{ }^{+}$ & $\mathrm{mg} / \mathrm{L}$ & 0.5 & 0.055 & 0 & 0.112 & 5 & 3.411 & 95 \\
\hline $\mathrm{HCO}_{3}{ }^{-}$ & $\mathrm{mg} / \mathrm{L}$ & 500 & 319 & 0 & 306 & 5 & 508 & 43 \\
\hline $\mathrm{Cl}^{-}$ & $\mathrm{mg} / \mathrm{L}$ & 250 & 12.1 & 0 & 39.3 & 0 & 106.0 & 10 \\
\hline $\mathrm{SO}_{4}{ }^{2-}$ & $\mathrm{mg} / \mathrm{L}$ & 250 & 8.5 & 0 & 88.8 & 5 & 63.5 & 0 \\
\hline $\mathbf{F}^{-}$ & $\mathrm{mg} / \mathrm{L}$ & 1.5 & 0.11 & 0 & 0.01 & 0 & 0.45 & 10 \\
\hline $\mathrm{NO}_{3}{ }^{-}$ & $\mathrm{mg} / \mathrm{L}$ & 50 & 3.9 & 0 & 26.3 & 20 & 4.7 & 0 \\
\hline B & $\mu \mathrm{g} / \mathrm{L}$ & 1000 & 46.0 & 0 & 72.6 & 0 & 735.4 & 14 \\
\hline $\mathbf{F e}$ & $\mu \mathrm{g} / \mathrm{L}$ & 200 & 304.7 & 100 & 361.0 & 90 & 352.1 & 71 \\
\hline Mn & $\mu \mathrm{g} / \mathrm{L}$ & 50 & 1.6 & 0 & 54.1 & 25 & 109.4 & 48 \\
\hline $\mathrm{Cr}$ & $\mu \mathrm{g} / \mathrm{L}$ & 50 & 1.4 & 0 & 1.9 & 0 & 3.0 & 0 \\
\hline $\mathbf{P b}$ & $\mu \mathrm{g} / \mathrm{L}$ & 10 & 0.7 & 0 & 0.3 & 0 & 1.7 & 5 \\
\hline Se & $\mu \mathrm{g} / \mathrm{L}$ & 10 & 0.5 & 0 & 1.9 & 0 & 1.5 & 0 \\
\hline $\mathbf{N i}$ & $\mu \mathrm{g} / \mathrm{L}$ & 20 & 0.5 & 0 & 1.6 & 0 & 1.9 & 0 \\
\hline
\end{tabular}

\section{Results}

The Piper plot (Fig. 2) shows that the water type of all samples of the karst aquifer belong to Ca$\mathrm{HCO}_{3}$ water type. These waters are fresh and the hydrochemical figure derives from the calcite dissolution, which is present in limestones. The alluvial aquifer includes $\mathrm{Ca}-\mathrm{HCO}_{3}$ and $\mathrm{Ca}-\mathrm{Mg}$ $\mathrm{HCO}_{3}$ water types due to calcite and dolomite dissolution, which are the dominant minerals of the aquifer. On the other hand, the Neogene aquifer shows a clear trend towards the $\mathrm{Na}-\mathrm{HCO}_{3}$ water type, indicating thus a freshening process of the aquifer through intense ion-exchange phenomena (Appelo and Postma, 1993). The dominant exchange is $\mathrm{Ca}^{2+}$ for $\mathrm{Na}^{+}$with a parallel increase in $\mathrm{HCO}_{3}{ }^{-}$. This is explained because when $\mathrm{Ca}^{2+}$ exchanges for $\mathrm{Na}^{+}$the water becomes undersaturated for calcite and dissolution results. The ion-exchange process is enhanced in the Neogene aquifer because of the increased adsorption capacity of the materials which is linked to the clay content, clay minerals, organic matter and oxide or hydroxide content (Appelo and Postma, 1993).

The WQI (Table 2) of the karst aquifer shows that all groundwater samples belong to the "excellent" class and, consequently can be used for drinking safely. The alluvial aquifer samples fall into the "excellent" category for the $75 \%$ of the total, while $20 \%$ of the samples are of "good" quality and only $5 \%$ have "medium" quality. There are no samples with "poor" or "extremely poor" quality in this aquifer. The relative lower quality of the alluvial aquifer is related with manmade activities (fertilizers, septic tanks, etc) as the water table is near to surface and contamination is likely to occur. On the other hand, the water samples of the Neogene aquifer appear to all the quality classes from "excellent" to "extremely poor". About half of the samples (52.4\%) are of "excellent" and "good" quality, $28.6 \%$ are of "medium" quality and the remaining $19 \%$ of the samples have "poor" and "extremely poor" quality. The degradation of the groundwater quality is attributed to natural processes and intense ion-exchange phenomena linked to the increased content of organic matter in the coal seam beds of the area. 


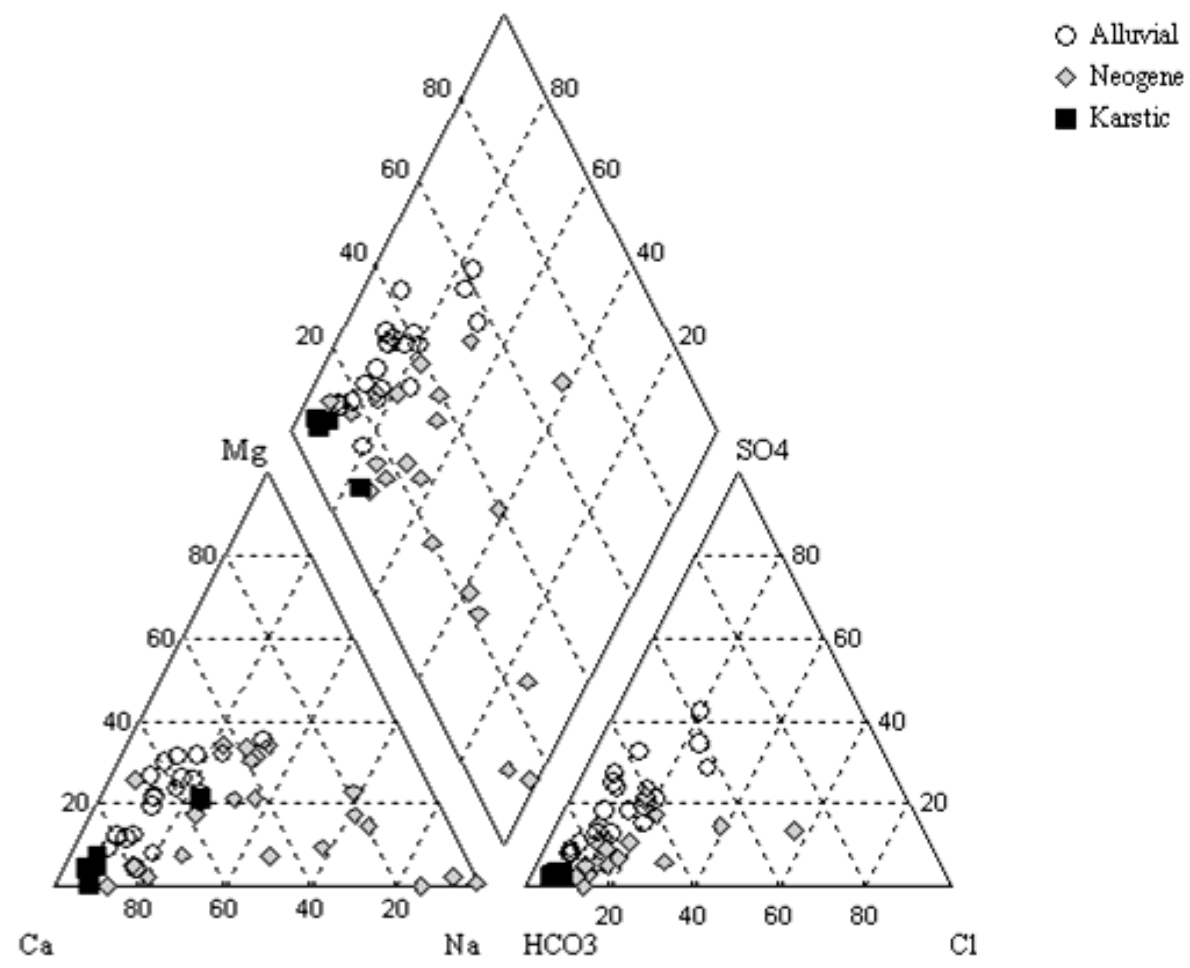

Figure 2 - Piper plot of the Zacharo basin aquifers.

Table 2 - Groundwater quality classification based on WQI.

\begin{tabular}{|l|l|l|l|l|l|l|l|l|}
\hline \multirow{2}{*}{ Rank } & \multirow{2}{*}{ WQI } & Water quality & \multicolumn{2}{|c|}{ Alluvial } & \multicolumn{2}{c|}{ Neogene } & \multicolumn{2}{c|}{ Karstic } \\
\cline { 4 - 9 } & & & $\begin{array}{l}\text { No. of } \\
\text { samples }\end{array}$ & $\mathbf{\%}$ & $\begin{array}{l}\text { No. of } \\
\text { samples }\end{array}$ & $\mathbf{\%}$ & $\begin{array}{l}\text { No. of } \\
\text { samples }\end{array}$ & $\%$ \\
\hline $\mathbf{1}$ & & & 15 & 75,0 & 3 & 14.3 & 5 & 100,0 \\
\hline $\mathbf{2}$ & $50-100$ & Gxcellent & 4 & 20,0 & 8 & 38.1 & 0 & 0,0 \\
\hline $\mathbf{3}$ & $100-150$ & Medium & 1 & 5,0 & 6 & 28.6 & 0 & 0,0 \\
\hline $\mathbf{4}$ & $150-200$ & Poor & 0 & 0,0 & 2 & 9.5 & 0 & 0,0 \\
\hline $\mathbf{5}$ & $>200$ & Extremely poor & 0 & 0,0 & 2 & 9.5 & 0 & 0,0 \\
\hline
\end{tabular}

The irrigation water quality parameters, i.e. SAR (Table 3), Percent sodium (Table 4), Residual Sodium Carbonate (Table 5) and Kelly's ration (Table 6) indicate that the groundwater of the karstic and alluvial aquifer is of "excellent" quality, and thus it can be used for irrigation safely. On the contrary, the groundwater of the Neogene aquifer is unsuitable for irrigation in a percent varying between 5\% and 33\%. According to SAR values (Table 3) $4.8 \%$ of these samples are unsuitable for irrigation. The Percent sodium index (Table 4) increases the unsuitability of the samples to $15 \%$ while $10 \%$ are doubtful for irrigation Finally, the RSC index and the Kelly's ratio illustrate that the $33 \%$ of the samples are unsuitable for irrigation. The problematic character of the Neogene aquifer for irrigation purposes is attributed to the enhanced ion-exchange processes that take place, which result in the increased content of sodium in the groundwater due to its exchange with calcium and other bivalent cations. 
Table 3 - Irrigation water quality classification based on SAR ${ }^{1}$.

\begin{tabular}{|l|l|l|l|l|l|l|l|l|}
\hline \multirow{2}{*}{$\begin{array}{l}\text { Ran } \\
\text { k }\end{array}$} & \multirow{2}{*}{ SAR } & Quality & \multicolumn{2}{|c|}{ Alluvial } & \multicolumn{2}{c|}{ Neogene } & \multicolumn{2}{c|}{ Karstic } \\
\cline { 4 - 9 } & & $\begin{array}{l}\text { No. of } \\
\text { samples }\end{array}$ & $\mathbf{\%}$ & $\begin{array}{l}\text { No. of } \\
\text { samples }\end{array}$ & $\mathbf{\%}$ & $\begin{array}{l}\text { No. of } \\
\text { samples }\end{array}$ & $\mathbf{\%}$ \\
\hline $\mathbf{1}$ & $0-10$ & Excellent & 20 & 100.0 & 18 & 85.7 & 5 & 100.0 \\
\hline $\mathbf{2}$ & $10-18$ & Good & 0 & 0.0 & 2 & 9.5 & 0 & 0.0 \\
\hline $\mathbf{3}$ & $18-26$ & Fair & 0 & 0.0 & 0 & 0.0 & 0 & 0.0 \\
\hline $\mathbf{4}$ & $>26$ & Poor & 0 & 0.0 & 1 & 4.8 & 0 & 0.0 \\
\hline
\end{tabular}

${ }^{1} S A R=\frac{N a^{+}}{\sqrt{\frac{C a^{2+}+M g^{2+}}{2}}}$, units in meq/lt

Table 4 - Irrigation water quality classification based on Percent sodium (\% $(\%)^{2}$.

\begin{tabular}{|l|l|l|l|l|l|l|l|l|}
\hline \multirow{2}{*}{ Rank } & \multirow{2}{*}{ Na } & \multirow{2}{*}{ Quality } & \multicolumn{2}{|c|}{ Alluvial } & \multicolumn{2}{c|}{ Neogene } & \multicolumn{2}{c|}{ Karstic } \\
\cline { 3 - 9 } & & & $\begin{array}{l}\text { No. of } \\
\text { samples }\end{array}$ & \% & $\begin{array}{l}\text { No. of } \\
\text { sample } \\
\text { s }\end{array}$ & $\mathbf{\%}$ & $\begin{array}{l}\text { No. of } \\
\text { samples }\end{array}$ & $\%$ \\
\hline $\mathbf{1}$ & $<20$ & Excellent & 16 & 80.0 & 3 & 15.0 & 5 & 100.0 \\
\hline $\mathbf{2}$ & $20-40$ & Good & 4 & 20.0 & 10 & 50.0 & 0 & 0.0 \\
\hline $\mathbf{3}$ & $40-60$ & Permissible & 0 & 0.0 & 3 & 15.0 & 0 & 0.0 \\
\hline $\mathbf{4}$ & $60-80$ & Doubtful & 0 & 0.0 & 2 & 10.0 & 0 & 0.0 \\
\hline $\mathbf{5}$ & $80-100$ & Unsuitable & 0 & 0.0 & 3 & 15.0 & 0 & 0.0 \\
\hline
\end{tabular}

$2 \% N a=\frac{N a^{+}}{C a^{2+}+M g^{2+}+N a^{+}+K^{+}} x 100$, units in meq $/ \mathrm{lt}$

Table 5 - Irrigation water quality classification based on RSC $^{3}$.

\begin{tabular}{|l|l|l|l|l|l|l|l|l|}
\hline \multirow{2}{*}{$\begin{array}{l}\text { Ran } \\
\mathbf{n}\end{array}$} & \multirow{2}{*}{ RSC } & Quality & \multicolumn{2}{|c|}{ Alluvial } & \multicolumn{2}{c|}{ Neogene } & \multicolumn{2}{c|}{ Karstic } \\
\cline { 4 - 10 } & & $\begin{array}{l}\text { No. of } \\
\text { samples }\end{array}$ & $\mathbf{\%}$ & $\begin{array}{l}\text { No. of } \\
\text { samples }\end{array}$ & $\mathbf{\%}$ & $\begin{array}{l}\text { No. of } \\
\text { samples }\end{array}$ & $\%$ \\
\hline $\mathbf{1}$ & $<1.25$ & Safe/good & 20 & 100.0 & 14 & 66.7 & 5 & 100.0 \\
\hline $\mathbf{2}$ & $1.25-2.50$ & $\begin{array}{l}\text { Marginal } \\
\text { /doubtful }\end{array}$ & 0 & 0.0 & 0 & 0.0 & 0 & 0.0 \\
\hline $\mathbf{5}$ & $>2.50$ & Unsuitable & 0 & 0.0 & 7 & 33.3 & 0 & 0.0 \\
\hline
\end{tabular}

${ }^{3} \mathrm{RSC}=\left(\mathrm{CO}_{3}{ }^{2-}+\mathrm{HCO}_{3}{ }^{-}\right)-\left(\mathrm{Ca}^{2+}+\mathrm{Mg}^{2+}\right)$, units in meq/lt

Table 6 - Irrigation water quality classification based Kelly's ratio (KR) ${ }^{4}$.

\begin{tabular}{|l|l|l|l|l|l|l|l|l|}
\hline \multirow{2}{*}{$\begin{array}{l}\text { Ran } \\
\mathbf{k}\end{array}$} & \multirow{2}{*}{ KR } & Quality & \multicolumn{2}{|c|}{ Alluvial } & \multicolumn{2}{c|}{ Neogene } & \multicolumn{2}{c|}{ Karstic } \\
\cline { 4 - 9 } & & & $\begin{array}{l}\text { No. of } \\
\text { samples }\end{array}$ & $\mathbf{\%}$ & $\begin{array}{l}\text { No. of } \\
\text { samples }\end{array}$ & $\mathbf{\%}$ & $\begin{array}{l}\text { No. of } \\
\text { samples }\end{array}$ & $\mathbf{\%}$ \\
\hline $\mathbf{1}$ & $<1.0$ & Suitable & 20 & 100.0 & 14 & 66.7 & 5 & 100.0 \\
\hline $\mathbf{2}$ & $>1.0$ & Unsuitable & 0 & 0.0 & 7 & 33.3 & 0 & 0.0 \\
\hline
\end{tabular}

${ }^{4} K R=\frac{N a^{+}}{C a^{2+}+M g^{2+}}$, units in meq/lt 


\section{Conclusions}

The hydrogeological and hydrochemical study that took place in the Zacharo basin showed that the karstic aquifer is the most important aquifer body with extensive reserves and excellent quality for both drinking and irrigation purposes. The alluvial aquifer can be used safely for irrigation but in some sites is contaminated due to anthropogenic activities, which limit its use for covering the drinking demands. Finally, the enhanced ion-exchange phenomena that take place in the Neogene aquifer as a result of the increased clay and organic matter content have deteriorate the groundwater quality for all uses. Especially, the increased concentration of sodium which replaces calcium renders the groundwater of this aquifer unsuitable for irrigation for the $33 \%$ of the sampling sites.

\section{References}

American Public Health Association (APHA), 2005. Standard method for examination of water and wastewater, 21st ed. APHA, AWWA, WPCF, Washington.

Amiri, V., Sohrabi, N. and Dadgar, M.A., 2015. Evaluation of groundwater chemistry and its suitability for drinking and agricultural uses in the Lenjanat plain, central Iran, Environ. Earth Sci., 74, 6163-6176.

Appelo, C.A.J. and Postma, D., 1994. Geochemistry, groundwater and pollution, A.A. Balkema, Rotterdam, Netherlands, $536 \mathrm{pp}$.

Kallergis, G. and Lambrakis, N., 1992. Contribution á l' etude des sources thermominérales de Kaifa, Hydrologie, 3, 127-136.

Panagopoulos, G. and Lambrakis, N., 1999. Hydrogeological conditions in the lower part of river Nedas catchment area, Proc. of the 5th Panhellenic Hydrogeological Congress, Nicosia, Cyprus, 12-14 November, 231-243.

Poonam, T., Tanushree, B. and Sukalyan, C., 2013. Water Quality Indices - Important tools for water quality assessment: a review, International Journal of Advances in Chemistry, 1(1), 15-28.

Ravikumar, P., Mehmood, M.A. and Somashekar, R.K., 2013. Water quality index to determine the surface water quality of Sankey tank and Mallathahalli lake, Bangalore urban district, Karnataka, India, Appl. Water Sci., 3, 247-261.

Vasanthavigar, M., Srinivasamoorthy, K., Vijayaragavan, K., Rajiv Ganthi, R., Chidambaram, S., Anandhan, P., Manivannan, R. and Vasudevan, S., 2010. Application of water quality index for groundwater quality assessment: Thirumanimuttar sub-basin, Tamilnadu, India, Environ. Monit. Assess., 171, 595-609. 